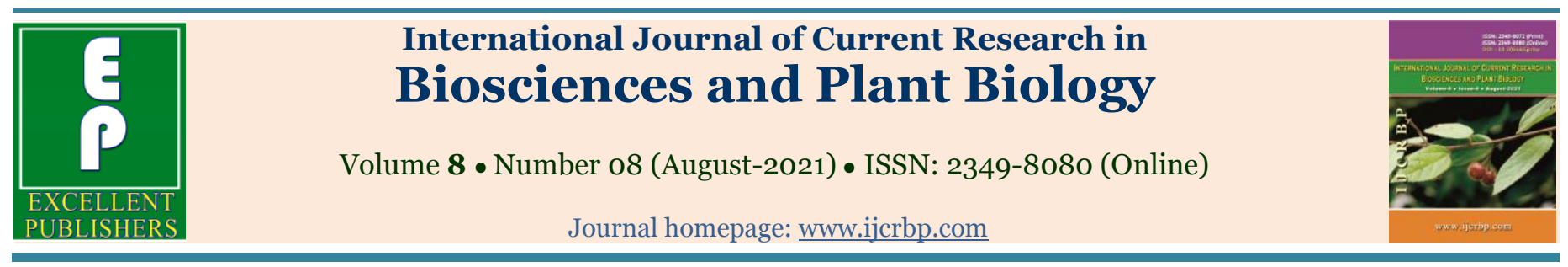

Original Research Article

doi: $\underline{\text { https://doi.org/10.20546/ijcrbp.2021.808.002 }}$

\title{
Gnaphalium pulvinatum Delile (Asteraceae): A new record for the flora of Kachchh district, Gujarat, India
}

\author{
Kazbanu A. Sumra ${ }^{1}$, Kishan I. Prajapati ${ }^{2}$, Jignasaba R. Jadeja ${ }^{1}$, Paurav K. Mehta ${ }^{3}$ \\ ${ }^{I}$ Department of Earth \& Environmental Science, Krantiguru Shyamji Krishna Verma Kachchh University, \\ Bhuj-Kachchh, Gujarat - 370001 India \\ ${ }^{2}$ Vande Vasundhra Research Laboratory, Bhuj-Kachchh, Gujarat-370001, India \\ ${ }^{3}$ Government Science College, Mandvi-Kachchh, Gujarat-370465, India \\ *Corresponding author; e-mail: kazbanu111@gmail.com
}

\begin{tabular}{|c|c|}
\hline Article Info & Abstract \\
\hline $\begin{array}{l}\text { Keywords: } \\
\text { Bhuj } \\
\text { Gnaphalium pulvinatum } \\
\text { Gujarat } \\
\text { Kachchh } \\
\text { Kundh }\end{array}$ & $\begin{array}{l}\text { Gnaphalium pulvinatum Delile (Asteraceae) has been reported first time as a new record to the flora } \\
\text { of Kachchh district from 'Kundh' pond of Ratiya forest of Bhuj taluka. A description, distribution } \\
\text { and detail photographs of the species are provided to easy identification. }\end{array}$ \\
\hline
\end{tabular}

\section{Introduction}

Asteraceae family is one of the largest plant families of angiosperms with over 25,000 species and 1600 genera distributed throughout the world. In India, the family is represented by 1052 species under 161 genera (Kanchan Lata, 2017). The genus Gnaphalium L. an herb distributed worldwide comprises approximately 200 species of the Asteraceae family that belongs to the tribe Gnaphalieae (Zheng, et al., 2013). Total 14 species were reported in Indian Himalayan region (Singh at al., 2019). For Gujarat state, 4 species are reported by different authors (Shah, 1978; Kumar 2011; Solanki 2015; Shah at al., 2015; Parmar 2012; Patel at al., 2021).
During the floristic explorations in January 2021, the author collected a specimen of the family Asteraceae from forest area of Ratiya village, of Bhuj taluka in Kachchh district (Fig. 1). After preliminary laboratory studies it has been identified as a species of Gnaphalium. The identity of the specimen was further confirmed by referring to the published flora (Bhandari, 1990).This confirmed that the species as Gnaphalium pulvinatum. This species has not been reported in earlier literatures of kachchh flora (Blatter, 1908; Shah, 1978; Pandey et al., 2009; Patel et al., 2011). Therefore, Gnaphalium pulvinatum Delile is a new addition to the flora of Kachchh and also additional distribution record to the flora of Gujarat. The voucher specimens were deposited at Government Science College, MandviKachchh, Gujarat, India. 


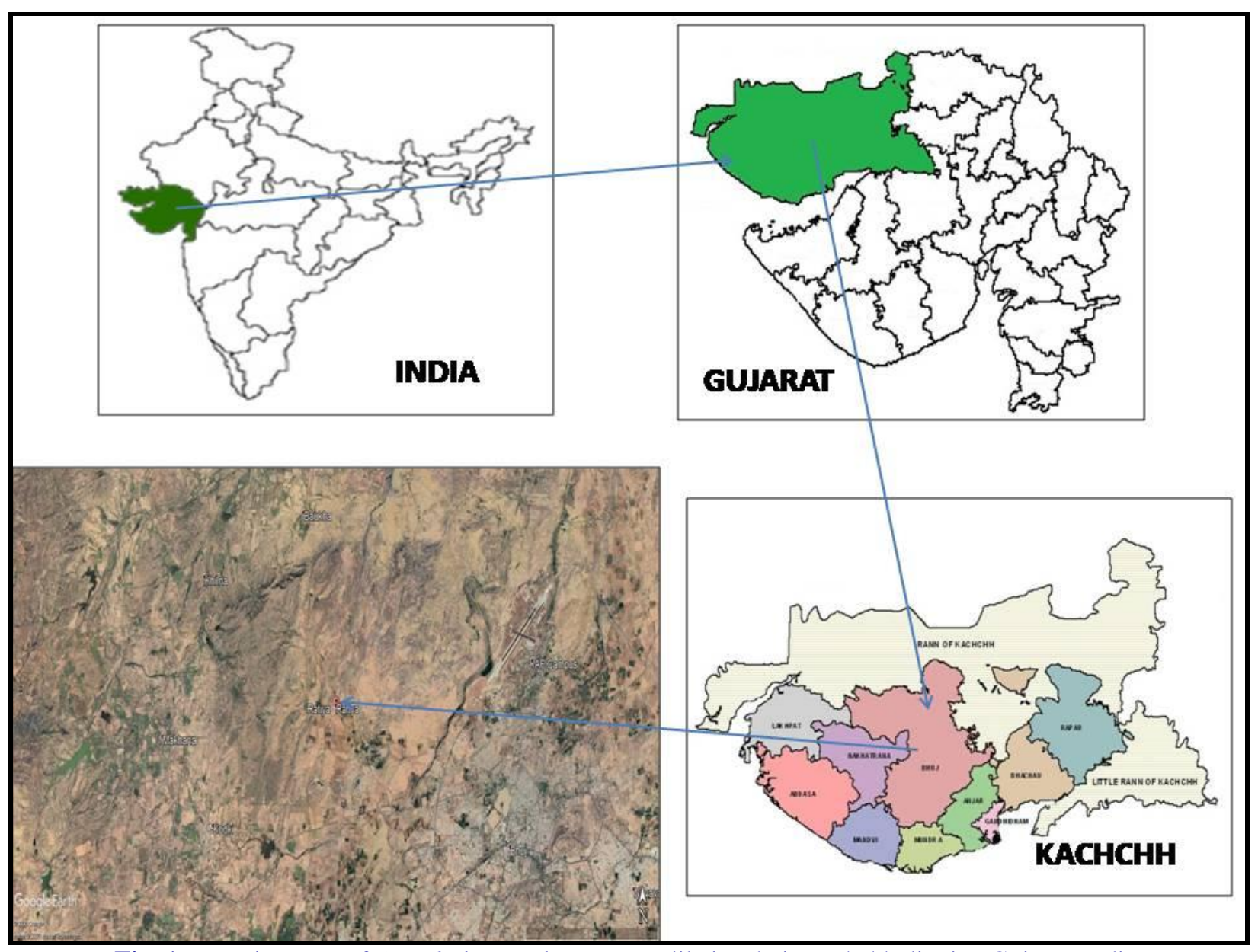

Fig. 1: Location map of Gnaphalium pulvinatum Delile in Bhuj, Kachchh district, Gujarat, India.

\section{Taxonomic description}

Gnaphalium pulvinatum Delile, Bhandari, Fl. Ind. Des. 180.1990, Blatter. FK, 776. 1908, Hook. F. FBI. 3: 289.1881 Cook. FPB. 2:31.1904, Shah.FGS.1:383.1978.

Small, prostrate, wooly, annual herb, numerous, branched, spreading, $5 \mathrm{~cm}-16 \mathrm{~cm}$ long; leaves 0.3$1.5 \mathrm{~cm} \times 0.2-0.5 \mathrm{~cm}$, spathulate, more or less obovate, sessile or sometimes attached at a based with short petiole, , hairy, heads $0.4 \mathrm{~cm}-0.8 \mathrm{~cm}$, terminal, immersed with wool, in leafy clusters, pale to brown colour, achiness minutes, oblong, papilose.

\section{Flowering and fruiting}

January-March.

\section{Specimen examined}

India, Gujarat, Kachchh, Bhuj, Ratiya, Kundh pond,
23017'31.4”N 69036'33.9”E, KKJ005, Dt. 26/01/2021; KKJ006 Dt. 07/02/2021, KKJ007 Dt.11/03/2021 (Fig. 2).

\section{Distribution}

World: Egypt, India, Myanmar, Pakistan, Saudi Arabia, Sinai, Sudan, China, etc.

India: Uttar Pradesh, Andhra Pradesh, Gujarat, Bihar, Himalayan Region, Maharashtra, Rajasthan, Kerala, Assam, Karnataka etc. Gujarat: Vadodara, Sabarkantha, Bharuch, Ahmadabad, Gandhinagar, Tapi, etc.

\section{Filed notes}

It is growing on wet soils around the margin of pond during winter season. It is strongly associated with Gnaphalium polycaulon Pers. and Grangea maderaspatana (L.) Poir. Also associated with Coldenia procumbens L., Heliotropium ovalifolium Forsk.; 
Polygonum plebeium R. Br. var. indica (Heyne exRoth) Hook.; Alternanthera sessilis (L.) DC.; grasses and sedges (several species of Cyperus, Fimbristylis and Scirpus genera); while Typha angustifolia L. and
Cyprus sp. growing on the margin of the pond. The population of this Gnaphalium L. species is about 35-40 individuals of this species were found from the current locality.
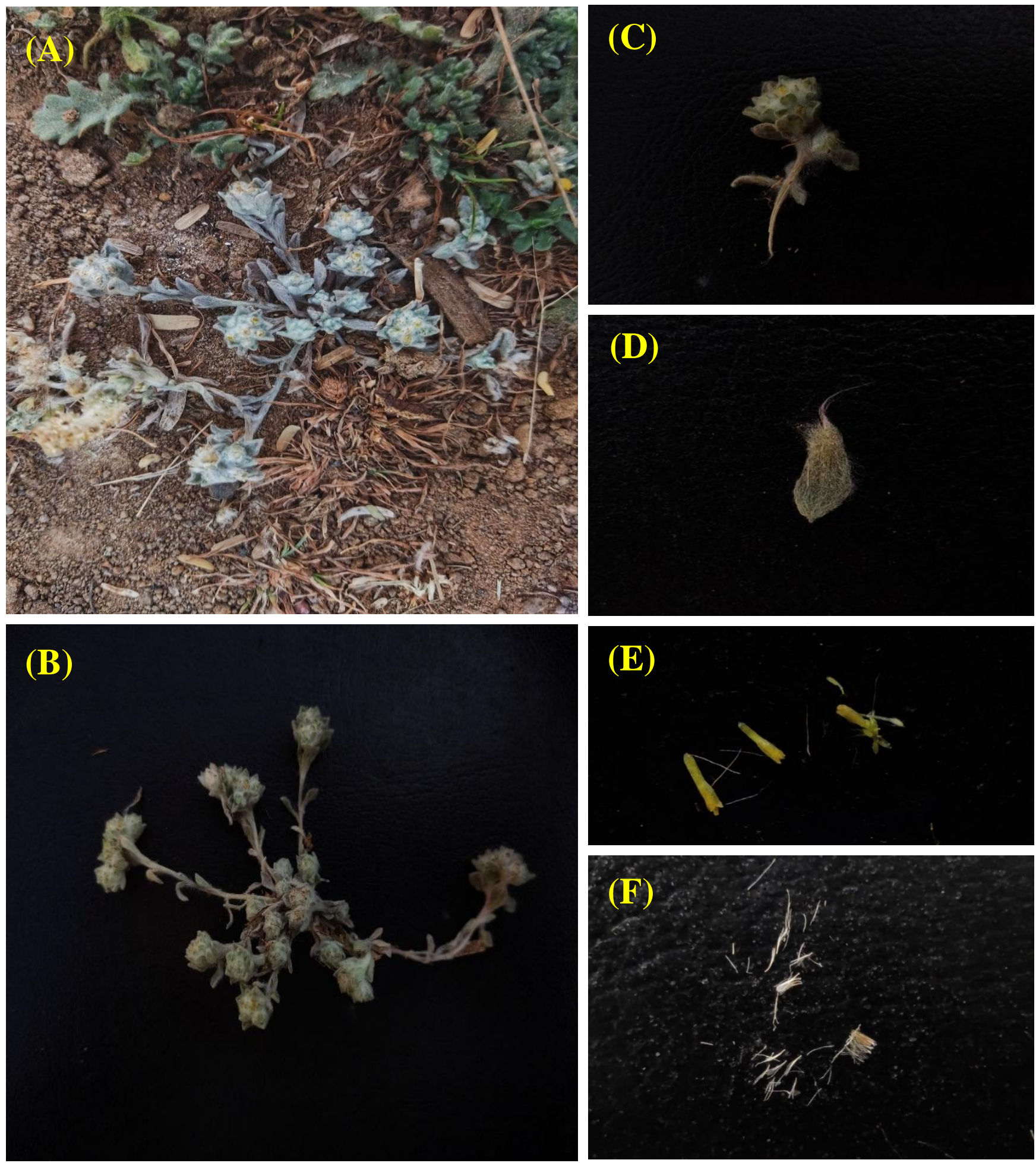

Fig. 2: Gnaphalium pulvinatum Delile. (A) and (B) Plant habit and association; (C) Separate wholl; (D) Leaf; (E) Separate florets; (F) Echiness. 


\section{Conservation recommendence}

During the field, it was observed by authors that this species has only expanded to an area of $8 \times 8$ meter of the present area at the edges of the pond therefore conservation of this species is essentials. Many threats in this area were found to water pollution, spread of Prosopis juliflora (Sw) DC., excessive grazing pressure, habitat fragmentation; any other these all factors may reduce the number of the species in their natural habitat in the future. So, if there is to be an increase in the distribution and conservation of the species, there is an urgent need to control all these harmful activities.

\section{Conflict of interest statement}

Authors declare that they have no conflict of interest.

\section{Acknowledgement}

Authors are thankful to the Forest Department, BhujKachchh for permission to undertake field survey in the forest area of Bhuj Taluka of Kachchh District.

\section{References}

Bhandari, M. M., 1990. Flora of the Indian Desert. MPS Repros, Jodhpur. 180.

Blatter, E.J., 1908. On the Flora of Kutch. J. Bom. Nat. Hist. Soc., 773-776.

Cooke, T., 1908. The flora of the Presidency of Bombay. Taylor \& Francis, London, Vol. 2, pp.3031.

Hooker, J. D., 1882. Flora of British India. L. Reeve and Co., London.Vol. 3, pp.288-289.

Kanchan, L., 2017. Asteraceous flora of Terai region of
Eastern Uttar Pradesh, India. Flora Fauna (Jhansi), 23(1): 105-114.

Kumar, R., Kumar, R., 2011. Habitat preservation is a concern for conserving of Heliotropium rariflorum Stocks. In the forest of North Gujarat Region (NGR), Gujarat, India. J. Res. Biol., 1: 30-37.

Pandey, R. P., Singh, V., Parmar, P. J., 2009. Phytodiversity of the Narayan Sarovar Wildlife Sanctuary, Kachchh, Gujarat, India. Nelumbo, 51: 41-98.

Parmar, P. J., 2012. A checklist of the vascular plants of Sabarkantha District, Gujarat, India. Nelumbo. 54: 92-137.

Patel, P. K., Parekh, P. P., 2021. Gnaphalium pensylvanicum (Willd.) (Asteraceae): New distributional record from Gujarat State, India. Indian For., 147(2): 200-201.

Patel, Y., Patel, R., Joshi, P., Dabgar, Y., 2011. Study of the Angiosperm flora of Kachchh district, Gujarat, India. Life Sci. Leaflet., 19: 739-768.

Shah, G. L., 1978. Flora of Gujarat State. S. P. University, Vallabh Vidyanagar. Vol I, pp.382-383.

Shah, D. R., Dudani, S. N., Sankhwal, A. O., Gavali, D. J., 2015. Riparian vegetation of mini river in Vadodara, Gujarat. Int. J. Environ. Sci., 6(2): 30.

Sinha, B.K., Singh, P., Dash, S.S., 2019. Plants of Indian Himalayan Region, Botanical survey of India.

Solanki, H., Gamit, B., Maurya, R., Qureshimatva, U., 2015. Check List of Flowering Plants In Tapi District, Gujarat, India. Int. J. Adv. Res., 3: 1104 1123.

Zheng, X., Wang, W., Piao, H., Xu, W, Shi, H., Zhao, C., 2013. The genus Gnaphalium L. (Compositae): photochemical and pharmacological characteristics. Molecules (Basel, Switzerland), 18(7): 8298-8318.

\section{How to cite this article:}

Sumra, K. A., Prajapati, K. I., Jadeja, J. R., Mehta, P. K., 2021. Gnaphalium pulvinatum Delile (Asteraceae): A new record for the flora of Kachchh district, Gujarat, India. Int. J. Curr. Res. Biosci. Plant Biol., 8(8): 14-17.

doi: https://doi.org/10.20546/ijcrbp.2021.808.002 